\title{
COMPARISON OF DIFFERENT CYTOLOGICAL PARAMETERS OF THREE SPECIES OF OCIMUM
}

\author{
Trayee Biswas" and Sandip Mukhopadhyay ${ }^{1}$ \\ Rishi Bankim Chandra College, Naihati, West Bengal, India \\ Keywords: Chromosome, Karyotype, Morphology, Ocimum, Phylogeny
}

\begin{abstract}
Karyomorphological analysis of three species of the genus Ocimum $(O$. basilicum L., O. americanum L. and $O$. tenuiflorum L.) was carried out. Gross chromosome morphology of these species are nearly sub metacentric (Sm), nearly metacentric $(\mathrm{m})$ and metacentric $(\mathrm{M})$ in nature. The high values of mean chromosome length, total chromosome length of $O$. americanum followed by $O$. basilicum show their primitiveness. Whereas, lower values of these parameters in $O$. tenuiflorum denotes evolved nature of the species. All the three species of Ocimum showed high values of total forma percentage (TF\%) in conjunction with low coefficient of variation $(\mathrm{CV})$, which corresponds to the primitive status in the evolution of flowering plants and was placed in 3A class of Stebbins' system, indicating the presence of symmetrical karyotype in them. Karyotyping along with UPGMA based dendrogram analysis clearly separated $O$. basilicum L. and $O$. americanum L. in one cluster and $O$. tenuiflorum L. in a separate cluster with greater Euclidian distance.
\end{abstract}

In general, the genus Ocimum showed a wide range of chromosomes with graded karyotype (Kundu and Sharma 1988). In the present investigation comparative karyotype analysis of three related species has been used to describe patterns and directions of chromosomal evolution within the genus Ocimum and to infer the evolutionary role of karyotype changes. Detailed information regarding the chromosome architecture in higher plants can thus serve as a useful tool to understand their systematic relationships and for tracing the trend and direction of their evolution.

Cytological studies were made following propionic orcein squash technique (Sharma and Sharma 1980). For somatic chromosome analysis, healthy root tips of $O$. basilicum were pretreated in a solution of saturated aqueous paradichlorobezene (PDB) and with a trace of aesculin at $18-20^{\circ} \mathrm{C}$ for $3.5 \mathrm{hrs}$. Whereas, in case of $O$. americanum and $O$. tenuiflorum pretreatment was done in a solution of saturated aqueous paradichlorobezene (PDB) and $2 \mathrm{mM}$ hydroxyquinolene $(1: 1)$. The root tips were initially chilled at $4^{0} \mathrm{C}$ for $4-5 \mathrm{~min}$ and then kept at $18-20^{\circ} \mathrm{C}$ for $3.5 \mathrm{hrs}$. The root tips were fixed in $1: 2$ propionic ethanol for $3 \mathrm{hrs}$ and hydrolyzed in $1(\mathrm{~N}) \mathrm{HCl}$ for $12 \mathrm{~min}$ at $60^{\circ} \mathrm{C}$. After thorough washing in distilled water and removing all traces of acid, root tips were treated in $45 \%$ propionic acid and then stained in $2 \%$ propionic orcein solution for 3 hrs. Karyotype analysis was carried out by critically examining about 20 clear, wellscattered metaphase plates from different root tips of 10 plants of each species. Based on the karyotype data, a cluster analysis was carried out to exmine karyotype similarity among species. A data matrix of 3 operational taxonomic units (OTUs) $\times 8$ variables were used. The variables were mean chromosome length (MCL), mean chromosome volume (MCV), total forma percentage (TF\%), coefficient of variation (CV), number of chromosomes with median primary constriction (M), chromosomes with nearly median (m) primary constriction, number of chromosomes with submedian primary constriction $(\mathrm{Sm})$, and number of satellite chromosomes. The similarity matrices (Stat Soft, 2002. STATISTICA for Windows, computer program manual Stat Soft, Tulsa, Oklahoma) were used to construct dendrogram using the unweighed paired group method with arithmetic average (UPGMA) method.

\footnotetext{
*Author for correspondence: <trayeebsws@ gmail.com>. 'Centre of Advanced Study, Department of Botany,
} University of Calcutta, Kolkata, India. 
The present cytological investigation on chromosome number determination and karyotype analysis of three species of Ocimum revealed different chromosome numbers as $O$. tenuiflorum, $O$. basilicum and $O$. americanum with $2 \mathrm{n}=32,48$ and 72, respectively (Fig. 1) The chromosome number of these species clearly indicated different ploidy status though the basic numbers were

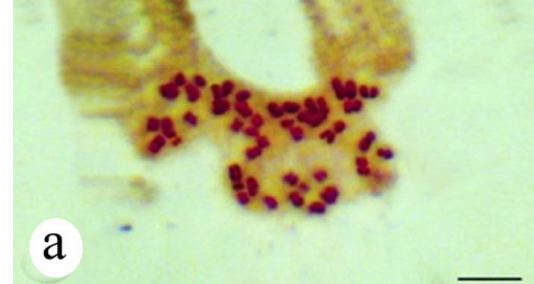

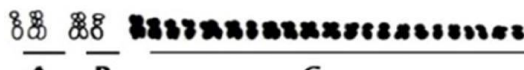

c
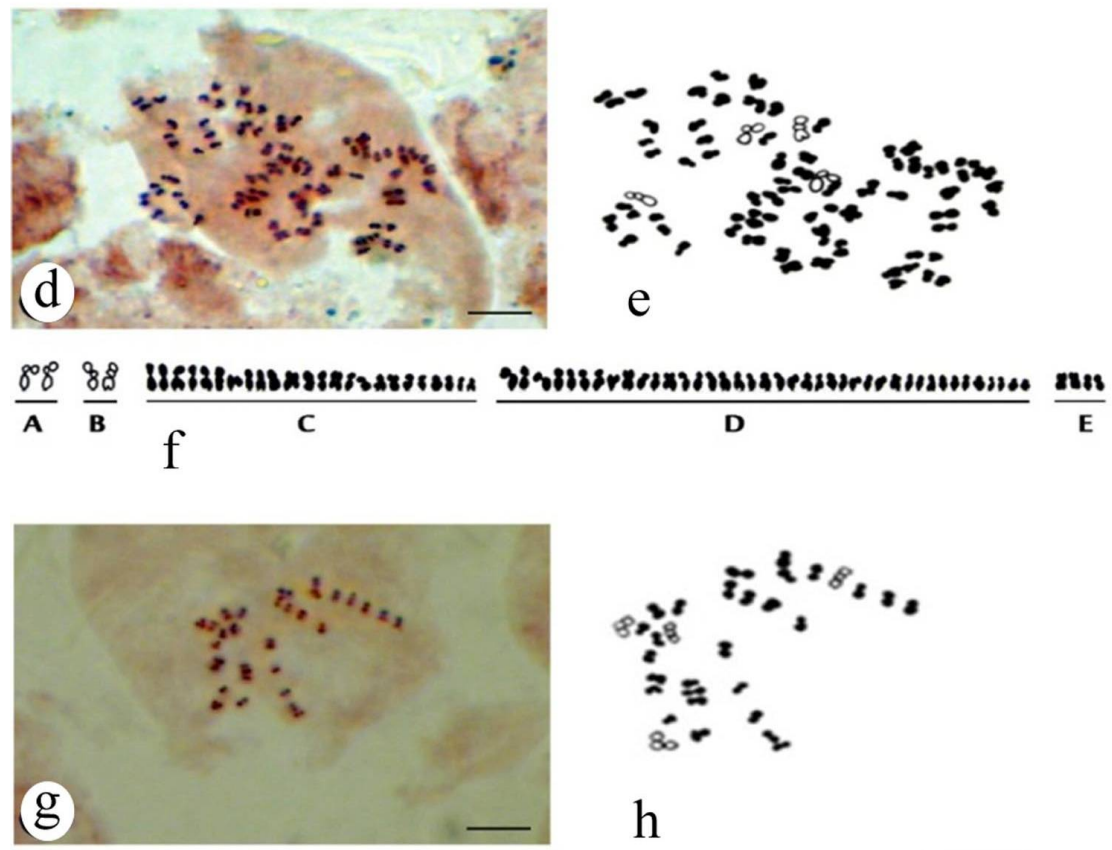

h

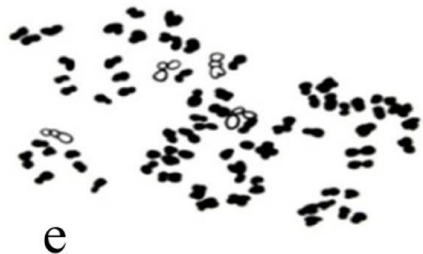

e
D

E

b

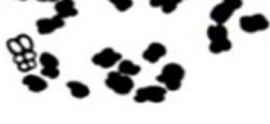

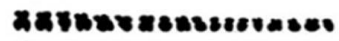

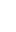

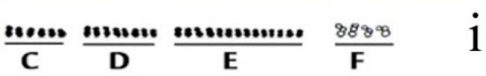


were little larger $(1.08-2.08 \mu \mathrm{m})$. In several species of angiosperms, a reduction in chromosome size has often been recorded along with polyploidy. Such fact was correlated with differential condensation, differential polynemy and other factors (Sharma 1970).

Table 1. Comparison of different cytological parameters of three species of Ocimum.

\begin{tabular}{|c|c|c|c|c|}
\hline \multirow{2}{*}{$\begin{array}{l}\text { Cytological } \\
\text { parameters }\end{array}$} & \multicolumn{4}{|c|}{ Plant material } \\
\hline & O. tenuiflorum & O. basilicum & O. americanum & F value* \\
\hline Somatic chromosome number & $2 n=32$ & $2 n=48$ & $2 n=72$ & \\
\hline $\begin{array}{l}\text { Chromosome pair with } \\
\text { secondary constriction }\end{array}$ & 2 & 2 & 2 & \\
\hline $\begin{array}{l}\text { Range of chromosome } \\
\text { length }(\mu \mathrm{m})\end{array}$ & $0.70-1.04$ & $1.08-2.08$ & $0.58-2.00$ & \\
\hline $\begin{array}{l}\text { Range of centromeric index } \\
(i \text { - value) }\end{array}$ & $31.58-50.0$ & $25.0-50.0$ & $25.25-50.0$ & \\
\hline $\begin{array}{l}\text { Total chromosome } \\
\text { length }(\mathrm{TCL})(\mu \mathrm{m})\end{array}$ & 25.520 & 76.240 & 116.208 & 106.32 \\
\hline $\begin{array}{l}\text { Mean chromosome } \\
\text { length }(\mathrm{MCL})(\mu \mathrm{m})\end{array}$ & $0.798 \pm 0.017$ & $1.589 \pm 0.049$ & $1.614 \pm 0.030$ & 26.10 \\
\hline $\begin{array}{l}\text { Total chromosome } \\
\text { volume }(\mathrm{TCV})\left(\mu \mathrm{m}^{3}\right)\end{array}$ & 14.302 & 107.232 & 179.251 & \\
\hline $\begin{array}{l}\text { Mean chromosome } \\
\text { volume }(\mathrm{MCV})\left(\mu \mathrm{m}^{3}\right)\end{array}$ & $0.447 \pm 0.013$ & $2.234 \pm 0.220$ & $2.489 \pm 0.180$ & \\
\hline $\begin{array}{l}\text { Total Forma percentage } \\
(\mathrm{TF} \%)\end{array}$ & 41.193 & 42.058 & 40.060 & \\
\hline Coefficient of variation (CV) & 13.904 & 21.219 & 17.640 & \\
\hline Karyotype formula & $\mathrm{C}_{8} \mathrm{D}_{6} \mathrm{E}_{14} \mathrm{~F}_{4}$ & $\mathrm{~A}_{2} \mathrm{~B}_{2} \mathrm{C}_{22} \mathrm{D}_{18} \mathrm{E}_{4}$ & $\mathrm{~A}_{2} \mathrm{~B}_{2} \mathrm{C}_{24} \mathrm{D}_{40} \mathrm{E}_{4}$ & \\
\hline $\begin{array}{l}\text { Degree of asymmetry } \\
\text { (Stebbins 1971) }\end{array}$ & $3 \mathrm{~A}$ & $3 \mathrm{~A}$ & $3 \mathrm{~A}$ & \\
\hline
\end{tabular}

$* p \leq 0.05$. Means were compared by one-way ANOVA of fixed effect and on the basis of analysis, it can be said that above $\mathrm{F}$ values are higher than the critical $\mathrm{F}$ value at the $5 \%$ level of significance.

However, the similar chromosome size among diploids and polyploids were also reported (Sharma 1974). The similarity in chromosome size and gross morphology between $O$. basilicum and $O$. americanum might have been due to the similar condensation index of chromosomes. All these species revealed graded karyotype with medium to short chromosome which may suggest their advance nature (Fig. 1) (Mukhopadhyay and Sharma 1987, Lahiri et al. 2009, 2010, Ray et al. 2009). So far as the chromosome's types were concerned $O$. tenuiflorum exhibited a complete different set of combination of chromosomes types in comparison to the other two species. $O$. basilicum and $O$. americanum revealing similar types and almost mere numbers of different chromosomes. In O. tenuiflorum the metacentric chromosomes were predominant $\left(\mathrm{E}_{14}\right)$ than median and sub median chromosomes. Moreover, a separate type of nucleolar chromosomes was observed in this species. On the other hand, both median and sub median chromosomes 
constituted the majority of the total chromosome complement than metacentric chromosomes in both $O$. basilicum and $O$. americanum In $O$. basilicum and $O$. americanum the nucleolar chromosomes were of two different types $\left(\mathrm{A}_{2} \mathrm{~B}_{2}\right)$ (Fig. 1). All these facts clearly suggested the involvement of minute structural alterations of chromosomes in the karyotype evolution of this species (Mukhopadhyay and Sharma 1984, Lahiri et al. 2010, Mukhopadhyay and Ray 2013). The range of centromeric index shows similarity between $O$. basilicum and $O$. americanum with a clear difference from $O$. tenuiflorum. The total chromosome length and total chromosome volume differed remarkably among three species. Similar results were also observed in mean chromosome length and volume, however, values of total forma percentage (TF \%) revealed similarity among these three species of Ocimum. The high values of mean chromosome length, total chromosome length of $O$. americanum followed by $O$. basilicum show their primitiveness. Whereas lower values of these parameters in $O$. tenuiflorum denotes their higher evolutionary status than other two. All three species of Ocimum studied showed high values of total forma percentage (TF\%, 40.06 - 42.058) in conjunction with low coefficient of variation (CV, 13.904 21.219), which corresponds to the primitive status in the evolution of flowering plants and were placed in 3A class of Stebbins' system, indicating the presence of symmetrical karyotype in them. Variation in karyotype details revealed phylogenetic relationship and affinities of three different species. UPGMA based dendrogram analysis clearly separated $O$. basilicum and $O$. americanum in one cluster and $O$. tenuiflorum in a separate cluster with greater Euclidian distance. Several other investigations using molecular marker, nuclear DNA values and chromosome morphology revealed the existence of more infra generic groups within this genus. The section Ocimum was divided into two separate clades; the genotypes belonging to $O$. basilicum clade were tetraploids, while varieties belonging to $O$. americanum clades were hexaploids. $O$. tenuiflorum belonging to a separate clade represented the most divergent species as far as the genetic distance was concerned. This group adds the smallest genome size organized in a few small chromosomes. The differences in genome size and chromosome numbers among Ocimum species suggested evolution of genomes might have been responsible due to sequence deletion or amplification, chromosome rearrangement and polyploidization as well (Carović-Stanko et al. 2006, 2010).

\section{Acknowledgements}

Financial assistance to the first author (TB) in the form of JRF and SRF (NET) (F. No. 09/028(0639)/2004-EMR-1) from the CSIR, New Delhi is gratefully acknowledged.

\section{References}

Bir SS and Saggoo MIS 1985. Cytological studies on members of family Labiatae from Kodaikkanal and adjoining areas (South India). Plant Sci. 94(46): 619-626.

Carović-Stanko K, Liber Z, Besendorfer V, Javornik B, Bohanec B, Kolak I and Satovic Z 2010. Genetic relations among basil taxa (Ocimum L.) based on molecular markers, nuclear DNA content, and chromosome number. Plant Syst. Evol. 285: 13-22.

Carović-Stanko K, Liber Z, Javornik B, Kolak I and Satovic Z 2006. Genetic relationships within basil (Ocimum) as revealed by RAPD and AFLP markers. Acta Hort. 760: 171-178.

Lahiri K, Mukhopadhyay MJ and Mukhopadhyay S 2009. Study of somatic chromosomes, estimation of 4C and 2C nuclear DNA content and RAPD analysis of two varieties of Mucuna pruriens L. Pers. Cytol. Genet. 14: 193-198.

Lahiri K, Mukhopadhyay MJ and Mukhopadhyay S 2010. Karyotype analysis and in situ 4C nuclear DNA quantification in two varieties of Mucuna pruriens L. J. Trop. Med. Plants 11: 219-225.

Mukhopadhyay S and Sharma AK 1984. Study of DNA content in the different species of Calathea at the interspecific level. Pers. Cytol. Genet. 4: 43-46.

Mukhopadhyay S and Sharma AK 1987. Karyomorphological analysis of different species and varieties of Calathea, Maranta and Stromanthe of Marantaceae. Cytologia 52: 821-831. 
Mukhopadhyay S and Ray S 2013. Chromosome and marker-based genome analysis of different species of Asparagus. Cytologia 78(4): 425-437.

Ray S, Mukhopadhyay MJ and Mukhopadhyay S 2009. Assessment of phylogenetic relationship among 4 species of Asparagus utilizing chromosomal and molecular markers. Pers. Cytol. Genet. 14: 185-192.

Sharma A K (1970) Polyploidy and chromosome size In: Darlington CD and Lewis KR (Eds.), Chromosome Today. London. pp. 248-252.

Sharma AK 1974. Plant cytogenetics. In: Busch H (Eds.), The Cell Nucleus. Academic Press, London. Vol. 11, pp. 264-287.

Sharma AK and Sharma A (Ed.) 1980. Chromosome Techniques: Theory and practice 3rd ed. Butterworths and Co. Ltd., London.

Singh TP and Sharma AK 1982. Chromosome evolution in Ocimum. The Nucleus 25: 59-64.

Stebbins GL (Ed.) 1971. Chromosomal evolution in higher plants. Columbia University Press, New York.

Verma BN 1980. Karyotype analysis in three species of Rhizocloniun Kutz. Cytologia 45: 433- 440. 